\title{
Indian writing in English: A Brief Study of some Indian Female English Writers
}

\author{
Hasina Jabeen \\ Research Scholar \\ Jiwaji Unversity Gwalior (M.P)
}

\begin{abstract}
English Language was introduced in India during British rule. Indians learned this colonial language and some Indian writers started writing in English. The first book written by an Indian in English was by Sake Dean Mahomet titled " Travels of Dean Mahomet " published in 1793. From that date that date the trend of English writing remained continue and today note male but female writers have made their own field. Female writers made their contribution through great novels poetry and prose. The paper provides a brief introduction of the writings and is based on secondary sources.
\end{abstract}

Keywords: English Language, Indian writers, contribution, prose and poetry

\section{INTRODUCTION}

English language has made prominent place in Indian societies and has become a dominant language. Though it is not official language in various areas but its influence could be observed from the education system of India. It has been used and still is used by official businessmen and writers. In Literature its role remained active from 18 th century to 21 st century. The past few years have witnessed a gigantic thriving of Indian writing in English in the global market. Indian writers have not only ' nativised' the British language in terms of stylistic features, but also accumulated English in terms of Indianised context. Now India has emerged as a major literary nation. Female English writers too used the British Style and made their contribution in the literature. Some of the prominent female English writers are Sarojni Naidu, Kamla Das, Arundhati Roy, Kiran Desai, Amrita Pritam etc. Their writings touch multidimensional themes and have been awarded at several times.

\section{Sarojini Naidu}

Sarojini Naidu was born on 13th February, 1879 in Hyderabad. Naidu was a keen reader and her outlook became very serious in nature. She contributed a lot in the freedom struggle of India. she served as the President of Indian National Congress in 1952. She toured the USA and Canada. In the world war II in 1939 she was arrested along with Gandhi and Nehru. she started her literary career at the age of 11 in 1890 when she wrote her first poem. She wrote a long poem " The Lady of the Lake consisting of 1300 lines in six days in 1892. In the same year she wrote a drama consisting of 2000 lines. Her first collection of poems " Golden Threshold" was published in 1905. It consists of forty lyrics on different subjects. The famous poems of this collection are 'Innovation to India' 'Lord Buddha Seated on Lotus'. Her second collection of poems titled " The Bird of Time " was published in 1912, in London. It contained forty-six lyrics with the theme of love. Her third collection of poems "The Broken Wing" was published in 1917 in London. It consists of sixty-one lyrics. Her other collections are The Sector Flute (1953) "The Feathers of Dawn" (1961) and "The Temple". She is called nightingale of India.

\section{Amrita Kour}

Amrita Kour was born on 31st August, 1919 in Punjab, now in Pakistan. Her father was also a poet. Amrita joined the progressive writer's movement and she also remained busy in social activities. She lived in relationship with Imroz a famous writer and artist. For many years she edited 'Nagmani' a monthly literary magazine in Punjabi. She wrote about hundred books of poetry, fiction, essays, biographies, autobiographies, Punjabi folk songs. Most of her literature reflect the terror of partition like Kushwant Singh she is known for partition literature. 
pinjar (The Skelton) is a famous novel, written in 1950, in this novel she creates her memorable character ' Puro' .This novel depicts the story of violence against women and massacre during partition on which an award winning film was made in 2003.

\section{Anita Desai}

Anita Desai Is an Indian novelist professor at the Massachusetts institute of Technology. She has been shortlisted for the booker prize for three times. She received a Sahitya Akademi Award in 1978 for her novel Fire on the Mountain and she also won the British Guardian Prize for her work The Village by the Sea." Cry the Peacock " is her first novel which was published in 1963. She creates her character Maya through whom she describes the horror of partition. In an insane condition she kills her husband. Desai has made a place in contemporary writers. She is one of the powerful novelist and she is also a psychological novelist. She depicts reality through her writings and her travelling enriches her writings. Another female writer who has got a prominent place among the female writers is Sheshi Desh Pandi. She has written eight novels and six collections of short stories and four children books. Her famous novel " The Dark Holds no Terror" portrays the life of a woman who becomes a victim of male dominance. In her next novel " Roots and Shadows " she presents a picture of a woman who refuses to accept traditional life. Desh Pandi becomes successful in applying stream-of- consciousness technic in her writings. Her writings deal with the crisis of woman. Desh Pandi won Sahitya Academy Award for her novel " The Long Silences.

\section{Arundhati Roy}

Arundhati Roy is luminary among the contemporary writers. Her writings deal with the plight of downtrodden and suppression of woman in male dominated society. Her writing career touched stars with her novel " The God of Small Things " which was sold just like melons. She got worldwide fame through this novel as it deals with suppression of women. Roy surprised the world with her first nonfictional work " The End of Imagination " in which she speaks about the nuclear tests conducted by India in 1998 at Pokham. Roy criticised the government of Indian for conducting nuclear tests without the consent of people. She made it a national issue through her writing and take it as a challenge. She had sympathy with the people who suffered a lot due to this project. Roy won Brooker Prize for her fiction " The God of Small Things " and was also nominated for the Sahitya Academy Award for the collection of essay" The Alegebra of Infinite Justice " in 2005.

\section{Conclusion}

Indian woman writers in English have made a great contribution in the world of literature. They excite with admirable aplomb as anthropologist, novelist, essayist, travel writers. They have excelled the global standards set by the post-colonial and postmodern writers. They are the mediators who reflect the core social and political problems. Their writings have excelled in the global literary field and their writings have achieved much academic attention.

\section{References}

1) Asnani, Shyam. New Dimensions of Indian English Novel. Delhi: Doaba House, 1987. Print. Barry, Peter. Biginning Theory: An introduction to literatary and Cultural theory. Manchester and New York: ManchesterUniversityPress. 1995. Print.

2) Betty, Frieday. The Feminine Mystique. New York. Dell, 1963. Print.

3) Deshpande, Shashi. That Long Silence, New Delhi: Penguin India, 1989. Print.

4) Mukherjee, Meenakshi. „ThePerishable Empire: Essays on IndianWritingin EnglishNew Delhi: OxfordUniversityPress.2000. Print.

5) Naik, M.K. A History of Indian English Literature. New Delhi: Sahitya Akademi. 1982. Print. Indian English Literature 1980-2000: A Critical Survey.Delhi: Pencraft International.2001. Print.

6) Ravi, P.S. Modern Indian Fiction: History, Politics and Individual in the Novels of salman Rushdie, Amitav Ghosh and Upamanyu Chatterjee New Delhi: Prestige Books, 2003. Print.

7) Robison, Lillian. In her work Sex, Class and Culture. 1978. Print. Sahgal, Nayantara. Plans for Departure 1989. Print.

8) Sen, Asha. „Towards a National Culture? India

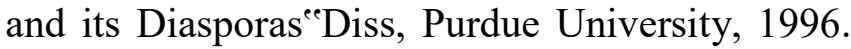
Print. "The Novels of Our Times," The Hindustan Times, 27 February 1993: 4. Print. Warner, Michael. "Literary studies and the History of the book": Book 12, 1987. Print. 